Paper received: Nov 132019

Paper accepted: Jan 202020

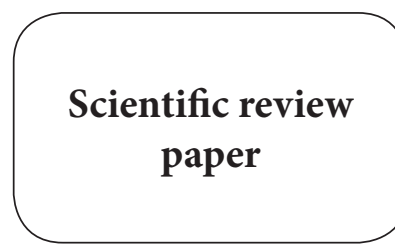

Charalampos E. Lemonidis ${ }^{1}$ University of Western Macedonia, School of Social Sciences and Humanities, Department of Educational Elementary Studies, Florina, Greece Anastasios C. Gkolfos 4th High School of Evosmos, Thessaloniki, Greece

\title{
Number line in the history and the education of mathematics
}

Summary: In modern mathematics curricula in primary and secondary education, number line is an important supervisory tool for understanding many concepts, such as different types of numbers, equations, and more. The use of the number line is supported by a large number of researchers, but there are also studies showing that students find it difficult to use.

Although the concept of number line is important for teaching and there is a great deal of debate about its use, as far as we know, there are very few systematic studies that examine the epistemological development of some components regarding the concept of number line throughout history and correlate this development by learning this concept from the students. However, there are no studies that examine the concept of historical development of the number line as a whole or relate it to student behavior.

In this paper, therefore, the first attempt has been made to examine the overall development of the concept of number line in the history of mathematics. We have therefore studied the historical evolution of the concept of number line and divided it into periods, according to the characteristics of this evolution. It seems that based on the slow mathematical integration of the concept of number line at the end of the 19th century, but also on some other critical points in the four historical periods that we have analyzed, some of the difficulties that students encounter when using it are likely to be epistemological obstacles.

Keywords: number line, historical evolution, epistemological obstacle, concept representation.

1 xlemon@uowm.gr

Copyright $\odot 2020$ by the authors, licensee Teacher Education Faculty University of Belgrade, SERBIA.

This is an open access article distributed under the terms of the Creative Commons Attribution License (CC BY 4.0) (https://creativecommons.org/licenses/by/4.0/), which permits unrestricted use, distribution, and reproduction in any medium, provided the original paper is accurately cited. 


\section{Introduction}

Despite its wide popularity, the use of the number line in mathematics education is rather new. It seems to have originated in the 1950s (Heeffer, 2011: 864). Many curricula and research show the use of the number line as a tool for teaching several mathematical concepts such as those presented below.

In the 1980s the empty number line (ENL) was introduced in the Netherlands in the framework of Realistic Mathematics for the early years' mathematics curriculum (Treffers, 1993). The graduated and empty number line is used for learning natural numbers, and for mental operations of addition and subtraction (Beishuizen, 1999; Murphy, 2011). The graduated number line and the empty number line are the appropriate material to assist students in a process of internalizing strategies in mental calculations (Murphy, 2008). The graduated number line is suitable for applying the counting process, which is directly related to the operation of addition.

Number line, used as a model for the representation of fractions, differs from other models of set and area - in important features (Bright, Behr, Post \& Wachsmuth, 1988; Petit, Laird \& Marsden, 2010). It can be used as a model for teaching percentages (Van den Heuvel-Panhuizen, 2003) and algebra for solving linear equations (Dickinson \& Eade, 2004).

The concept of epistemological obstacle appears for the first time in philosophy of science in the works of Bachelard (1938). Brousseau (1976, 1983) transferred this concept to the science of mathematics education. Apart from the epistemological obstacle, Brousseau distinguishes between the ontogenic obstacle which refer to the genetic development of intelligence and the didactical obstacles which express the difficulties created by the didactic choices. Concerning the epistemological obstacle, Brousseau points out that students' mistakes are theoretically not the result of ignorance or chance but rather an "effect of prior knowledge that was relevant and had its success, but which now proves to be false, or simply inadequate" (Brousseau, 1983). Epistemological obstacles are not easy to overcome because they play a crucial role in the construction of knowledge; however, they are necessary and their rejection must be arranged.

There have been several investigations relative to epistemological obstacles, including the research of numbers, such as the relative numbers in Glaeser (1981), rational and decimal numbers in Brousseau (1983), the absolute value in Duroux (1983) and Thomaidis (1995). There is also research on number line (mentioned below). This research can be related to the epistemological obstacles in terms of attempting to investigate and contrast the difficulties of students regarding the number line with the historical development of this concept.

Concerning a semiotic consideration of number line, Teppo \& van den Heuvel-Panhuizen (2014: 46) point out that number line is part of a 'semiotic representation', according to Duval's theory (Duval, 1999). These authors suggest that for a proper management of number lines one should identify the line's representational components, understand how these components show and convey information, as well as note Duval's statement "show the organization of relations between the representational units" (Duval, 1999: 13).

In this view, however, we must bear in mind that representational components of number line, such as geometric straight line and numbers, are also mathematical objects with important historical evolution, as we shall see below. According to Duval's (1988) theory, we can say that the number line results from the articulation of two different registers of representation, more specifically the geometric (Euclidean line) and the arithmetic (numbers) one.

Therefore, the objects that compose the number line and are articulated between them are mathematical ones, which in themselves have a cogni- 
tive state and a historical evolution in the history of mathematics.

In this study we first attempt to present relevant research and analyze the types of number lines, and then we present two studies examining components of number line, namely the direction and negative numbers based on historical evolution. Then a historical analysis of the evolution of number line is presented. After that, we present the difficulties encountered by students in using the number line as a representation tool, and through the historical evolution of the number line we try to contrast these difficulties with critical points in its historical evolution.

\section{The different types of number line}

Two studies can be found in the literature, which distinguish the different types of number lines. The one is by Diezmann, Lowrie \& Sugars (2010), while the other is by Teppo \& Van den Heuvel-Panhuizen (2014). The first research distinguishes between two types of number lines and the second among five. We present these distinctions of the number lines in the two studies further down.

Diezmann, Lowrie \& Sugars (2010) distinguish between two major types of number lines: structured number lines, which are the topic of this paper, and empty number lines. Structured number lines represent mathematical information by the placement of marks on a horizontal or vertical line which has been marked into proportional segments. Empty number lines are blank lines which students can use for calculations.

After studying the literature on number line, Teppo \& Van den Heuvel-Panhuizen (2014) found that there is a large variety of number lines. Thus, they have led to the creation of a framework for the classification of number lines, taking into account (1) the changes in their visual characteristics, (2) the type of numbers involved, (3) the way in which numbers and their operations are represented by a number line and (4) the teaching support provided by a number line. Based on this framework they grouped the number lines into five different types commonly found in mathematics textbooks for primary and secondary education and teacher education programs for these school levels.

The first type is the filled number lines, which are characterized by equidistant points representing natural numbers. This type of number line reflects the order of measurement, facilitates the activities of counting and placing numbers, as well as exploring the order of numbers and their relationships.

The second type is empty number lines, which focuses exclusively on the order of the numbers. The Empty Number Line (ENL) is characterized by points arranged, not necessarily equidistant over a section of a line. These points, which represent numbers, convey information about the relationships associated with the series of numbers. ENL is used to present the strategies of calculation. Starting from a freely placed point on such a line, students can draw a series of jumps to visualize the steps involved in performing a particular calculation.

The third type is the directed-length number lines, which use a concept of number measurement, where integers are represented by directed length lines that are determined both by size and direction. Numbers are displayed as lengths that are measured from zero. Directed-length number lines support arithmetic operations with integers and reasoning about the structure of these operations.

The fourth type is the rational number lines, where the unit interval is divided into equal intervals and the fractional numbers are represented as points. These lines display the sequences of measurement of fractional number and support the position of fractions and decimal digits. Parallel lines of rational numbers use sets of parallel lines with different unit spacing to show and justify equivalence relationships. 
And the fifth type is the proportional and double number line, where the numbers are represented by points that are proportional to the given limit values. It consists of a double scale line and shows pairs of points. Numbers above and below a single point represent an analogy used to justify a particular analogous relationship. They are used to display the approximate position of real numbers.

We consider that the empty number line is different from other forms of graduated or structured number lines, as called by Diezmann, Lowrie \& Sugars (2010). Graduated number lines are close to the mathematical object that is the axis. They are one or two lines where different sets of numbers can appear on them - natural, integer, rational and real numbers. The numbers are presented in proportional relations to each other and to the unitary intervals. While the empty number line has features that are different from the mathematical object representing the axis and it is a representation of it. In the empty number line, there are no unitary intervals, measures, and proportional relationships between the measures. The empty number line is therefore a representation farther from the mathematical object than the graduated number line.

According to the above, we distinguish three types of number lines:

1. The number lines that are mathematical objects, such as the axis, the representation of the inequalities in the axis, the vector line, etc.

2. The graduated or the structured number lines.

3. The empty number lines.

The first group of number lines or mathematical figures consists of combining lines or vectors with numbers and is used as a representation in various mathematical concepts such as the axis, illustrations of the inequations in the axis, multiplication of vector $(\mathrm{k} . \vec{v})$, representation of the homothety in line, etc. Thus, the first group is the representation of mathematical objects and it is the mathemat- ical number line like the axis. The second and third groups are axis representations and are those presented by Diezmann, Lowrie \& Sugars (2010) and Teppo \& Van den Heuvel-Panhuizen (2014) above.

In the present work we will mostly refer to the second type of number lines.

\section{Other research on the number line}

As far as we know, there are two studies (Heeffer, 2011; Thomaidis \& Tzanakis, 2007) which carry out a historical and epistemological analysis on the concept components of the number line. More specifically, they attempt to correlate the results of the historical analysis with the teaching processes and students' behaviors at school.

Thomaidis \& Tzanakis (2007) aimed to investigate the method of parallelism of the historical development with the behaviors and teaching in today's school classrooms and to ask questions concerning this method. For this purpose, the order relation was the only one to be examined from the components of the number line. They attempted to relate the development and function of the knowledge of order relation on the number line, both during its historical development and during the teaching and learning of order relation on the number line with 16-year-old Greek students.

The results of their historical research show that the modern version of the ordering on the real number line was introduced only in the 19th century, under the influence of the powerful currents of arithmetizing mathematics where numbers were conceived as quantities.

The contributions of mathematicians such as Stifel (1544), Descartes (1637), Euler (1770) and Cauchy (1821) are presented in an attempt to explore this historical evolution of the notion of order of real numbers on the number line. The authors also note that "till the end of the 18th century, there was a strong tendency to reject negative numbers by appealing to the 'quantitative' conception of 
number" (Pycior, 1987; Schubring, 1986). Concerning the parallelism between historical evolution and mathematics education these authors conclude that it has a subtle nature with at least two different aspects (metaphorically named "positive" and "negative"), which are worth further exploration.

In his work Heeffer (2011) argues that the number line may not be appropriate for the early teaching of operations involving negative numbers. Regarding this claim, he presents a number of arguments based on several discussions between philosophers and mathematicians such as Arnauld, Leibniz, Wallis, Euler and D'Alembert during the seventeenth and the eighteenth centuries. The author argues that not only the division between negative numbers creates problems for the number line, but also the idea of quantities smaller than anything is also disputed. Based on historical analysis, the author supports the introduction of negative numbers into education in the context of symbolic operations.

Another research on the number line concerning only the historical context is that of Amadeo (2018). In this research the intention was to understand the historical contexts that configure the emergence and development of the notion of the number line. For this purpose, Amadeo used historical textbooks to explore the number line, while contextualizing its use during its initial development period in the seventeenth century until its current use as in the nineteenth century. The relevant analytic geometry textbooks of that time have been explored, mainly from France and Germany, to understand when and how this notion was used. This study concludes that the number line "is a notion that is initially linked to the practices of analytic geometry, and that is established as a didactic resource in the analysis of curves from the algebraic expression of its variables. That is, the number line arises in the context of teaching. There is in Fischer's writing the first record of this notion only in the nineteenth century" (Amadeo, 2018: 919).

\section{Purpose of the research and research questions}

The main purpose of the present study is to examine the overall development of the concept of number line and its constituents in the history of mathematics and compare this development with the difficulties of individuals in learning this concept. More specifically the research questions posed are:

1. Is there a diachronical development in the history of mathematics on the notion of number line? Could this historical evolution be separated into different time periods?

2. Is it possible to draw some analogy between this historical evolution of the concept of the number line and the difficulties encountered by individuals in learning about this concept?

\section{Method}

The methodology we use in the present study is, on the one hand, historical analysis with a reference to sources, in order to investigate the historical evolution of the concept of number line in mathematics. On the other hand, there is a bibliographic analysis of the studies on the learning and the use of the number line in education to identify the various difficulties that students and adults face.

\section{Evolution of number line concept in the history of mathematics}

The evolution of the concept of the number line was an age-long process which is directly linked to the evolution of the concept of numbers and geometry. The idea of matching every single point of a line to a real number, as we know it today, emerged at the end of the 19th century. In this evolution we can distinguish four basic periods: 


\section{1st period. Mathematics up to Euclid: Separation of numbers and lines.}

The Egyptians, the Babylonians and the Chinese, whose cultures bear a significant mathematical tradition, developed sophisticated numerical processes, but there was no reference to a number line. While they knew important mathematical laws, could easily handle numbers and geometric shapes, and could solve difficult arithmetic problems that required an extraordinary logical ability, the reasons that led them to this mathematical development were entirely practical. The mathematics of the ancient people of the East focused solely on practical applications and geometrical problems that were solved within a strictly numerical framework.

However, some of the diagrams on Babylonian plates, such as the famous YBC 7289 plaque, written around the first third of the second millennium BC, show lines with numbers associated with the measurements.

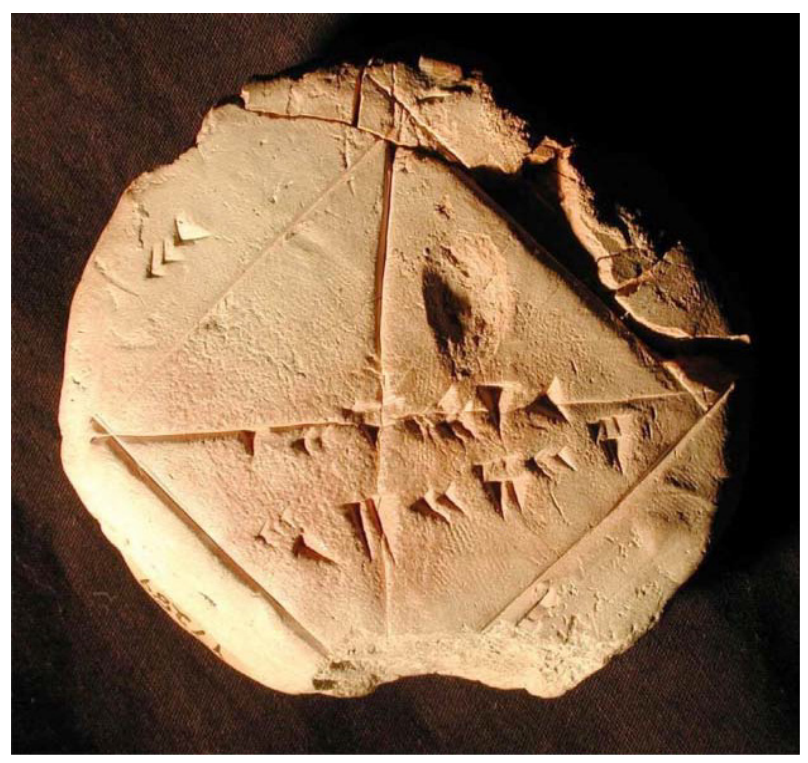

Figure 1. The Babylonian plate YBC 7289.

This does not mean, however, that the creators and users of such plates were operating in the sense of the number line (Núñez, 2011). The identi- fication of the points of a straight line with numbers was the result of the practical and algorithmic nature of the mathematics they used (Crossley, 1987).

In Greek mathematics there was a clear separation between number and magnitude. Numbers (natural numbers) were simply collections of discrete units that measured a multitude. Magnitude Size, on the other hand, was usually described as a continuous quantity divided into parts and is infinitely divisible (Bunt, Jones \& Bedient, 1981).

This distinction between number and magnitude also resulted in the distinction between arithmetic and geometry. Arithmetic dealt with the discrete or non-extended quantity, while geometry dealt with the continuous or extended quantity. It also imposed a different way of solving and handling many problems. The Babylonian arithmetic algorithms had to be replaced by a new geometric algebra which did not allow the addition of lines and areas or areas and volumes. There had to be strict homogeneity in the formulas used by the Mesopotamian people, which had to be interpreted geometrically (Boyer \& Merzbach, 1997). Thus, in ancient Greece geometry was transformed into a science, with Euclidean geometry studying abstract mental objects serving as an example.

The existence of incommensurable magnitudes led to the formulation of a new theory by Eudoxus presented in the Book V of "The Elements of Euclid". The separate interpretation of the ratios of sizes (proportion) and ratios of integers (fractions) is in line with the level reached by the Greek thought. Euclid does not seek to define what he means by magnitude. The theory he built does not depend on the kind of magnitudes examined and it is the one that ensures generality (Lemonidis, 1990).

This differentiation may lead to a categorization of the concept of number. On one hand, the concept of number as a means of measuring objects (natural numbers) and, on the other, as a means of measuring quantities (real numbers as presented today). The Greeks were the first to grasp the two 
forms of the number, perhaps because of their need to solve the problem of incommensurability. It is a distinction analogous to the present, with the differences between natural numbers when considered natural or real numbers.

The discovery of irrational numbers in ancient Greece was the result of comparisons between lengths or other quantities and became the focus of study for a long time. At that time there was no idea of identifying every point of a line with a number. The ancient Greeks were also unaware of the negative numbers (Bunt, Jones, \& Bedient, 1981). The identification of each real number with the points of a straight line was a gradual conception, which is primarily associated with the gradual change within the context of the concept of number.

\section{2nd period. Until the 16th Century: Foundations of Integers - Rational Numbers - Empirical Geometry}

A decline in the development of mathematics begins from the $3^{\text {rd }}$ century AD. However, the Greek geometrical heritage of Euclid, Archimedes, Apollonius and Menelaus was preserved and disseminated by the Byzantines to certain spiritual centers of the Arab world (Eves, 1997). During these years the character of Geometry remains very close to the character of the Geometry of Hellenistic times. On one hand, it follows the Greek geometric tradition of Euclid and on the other, the distinction between theoretical and practical geometry is established. From the 12th to the 16th century an orientation in empirical Geometry is observed, as well as its relation to computational methods and the use of measuring tools (Struik, 1982).

Michael Stifel (1487-1567) was the first to define negative numbers as numbers less than zero and positive numbers as greater than zero. He was the first to describe zero, fractional and irrational numbers as numbers (Sinkevich, 2015). In his work Arithmetica Integra (1544) he has an amazing geometric awareness of the number. He writes about inte- gers, rational and irrational numbers and how they are distributed among themselves, that is, their position in the line of numbers. He recognized that there are infinite fractions and irrational numbers between two consecutive integers, which can be interpreted as a demonstration of the density of those numbers. We observe that Stifel's recognition of negative numbers as numbers and their placement left of zero is a precursor to the notion of the number line, but also to the infinite number on it.

In the 16th century a transformation began in the classical conception of number and magnitude. Francois Viete (1540-1603) introduced a new form of symbolism to denote unknown magnitudes and numbers, stating that numbers and magnitudes can be interchanged. This relationship between numbers and magnitudes encouraged the idea that numbers could also be treated as if they were continuous in the Aristotelian sense of continuity (Neal, 2002).

Stevin (1548-1620) believed that the number was the measure of a quantity and that the numbers were continuous rather than discrete (Neal, 2002). Stevin also developed a system with decimal extensions of very complicated numbers, without the use of the decimal point, which made it more apparent that an unreasonable (irrational) number could be approached by a rational (Rogue, 2012) and at the same time implicitly contained the idea of a numerical continuous. It essentially meant that the numbers could be represented along a line (Neal, 2002).

Thus, in his work Arithmetique (1585) we find new mathematical concepts in which the unit is a number, any root is a number, any numbers can be square and there are no numbers that are unreasonable, irregular, unexplained (Lemonidis, 1990). Waerden (1985) typically states that Stevin's general concept of real numbers was accepted, implicitly or explicitly, by all subsequent scientists. Furthermore, Fearnley-Sander (1979), (citing Katz \& Katz, 2011), wrote that the modern concept of real number was first conceived by Simon Stevin, in about 1600, and 
developed into mathematics over the next two centuries.

However, even during this period there is no concept of the number line and the identification of each point with a number. Nevertheless, the elements that make it possible to display number line were beginning to emerge.

\section{$3 r d$ period. From the 17th century}

to the beginning of the 19th century:

The first connection between numbers and geometric line - Algebraization of geometry

Mapping the lines of numbers was not a common idea among mathematicians until the end of the 16 th century. However, the concept of the number line began to emerge in the 17 th century by some pioneering mathematicians (Núñez, 2011).

The concept of logarithm was invented in the early 17 th century as a means of simplifying arithmetic calculations. The main problem of mathematicians of the time was to construct sufficiently dense geometrical progressions to be inserted between their terms, without a significant error, numbers that often appeared in calculations. The terms of geometrical progression should simultaneously be put in a one-to-one correspondence with the terms of a numerical progression (Thomaidis, 1995). John Napier (1616), in his attempt to explain the definition of logarithm in his book A Description of the Admirable Table of Logarithmes, uses diagrams showing a line with numbers (Figure 2).

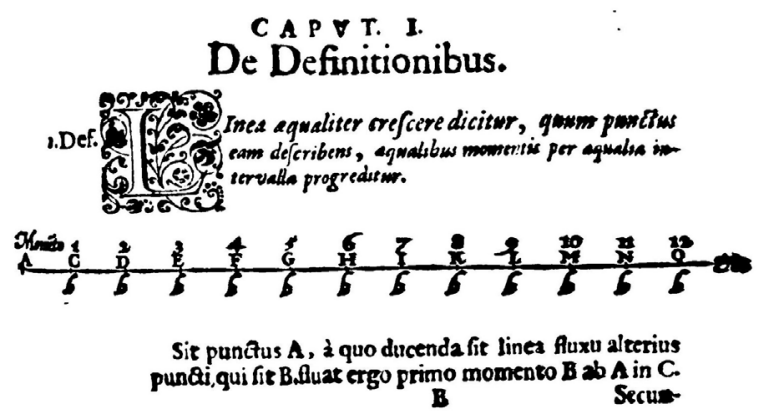

Figure 2. The concept of number line by Napier (1616).
However, John Wallis (1685) was the first to use a number line in his book, Treatise of Algebra (Figure 3), in order to interpret addition and subtraction with negative numbers, using the example of a man moving along a straight line starting at point A (Heeffer, 2011).

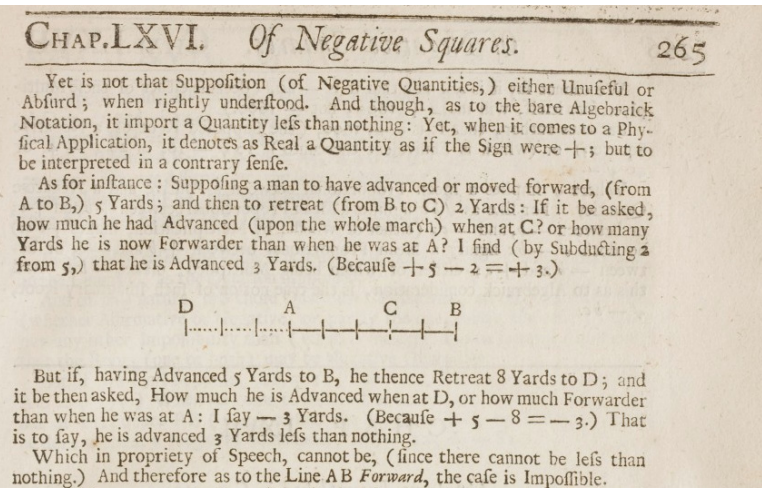

Figure 3. John Wallis introduces the number line into his algebra.

The development of algebraic symbolism and the connection of curves to their equations led Descartes to the algebraization of geometry with the help of the coordinate system. Thus, geometrical relations are expressed through an analytic functional dependence that leads Descartes to use the algebraic approach to find solutions to geometrical problems. The purpose of his method was, on one hand, to liberate geometry from the use of diagrams through the algebraic process, and on the other to give meaning to the functions of algebra through geometric interpretation.

In fact, however, the coordinate system is defined by lines that exist in the particular problem, irrespective of the angle they form. Also, Descartes does not use the terms abscissa, ordinate or axis in his work. Descartes did not introduce the number line through the discovery of the coordinate system in 1637 in his work La Géometrie, since he never mentions the concept of axis, and none of his illustrations depict an axis or a numerical system of coordinates even when the values for specific magnitudes are specified (Núñez, 2011). 
In the 18th century, Ephraim Chambers (1728) in his work Cyclopaedia or, An universal dictionary of arts and sciences displays for the first time the numbering of the points on one of the axes of the coordinate system. In the illustration of the ellipse (Figure 4) the main axis $\mathrm{AB}$ is delineated by the sequence $10,20,30, \ldots 90$.

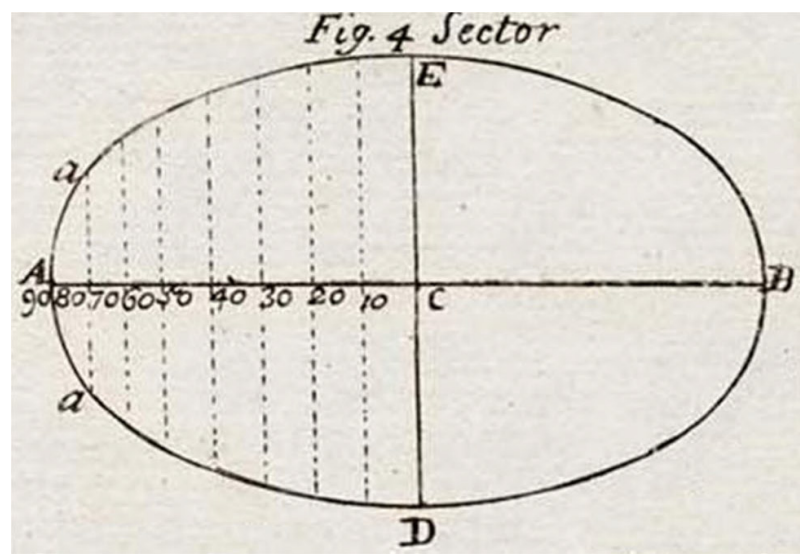

Figure 4. Chambers (1728, Trigonometry table).

However, these numbers do not correspond to some measures for the AC segment. Since this is an ellipse, Chambers makes a connection of the points marked by the angle formed by the ECa, where there would be the point of the ellipse. Thus, the values marked in line $\mathrm{AB}$ correspond to a number of angles and not to a variable $\mathrm{x}$ defined on the $\mathrm{AB}$ axis, beginning with $\mathrm{C}$.

The first recording of number lines appears in the first half of the nineteenth century in the work of Ernst Gottfried Fischer (1754-1831). Fischer works with negative and positive quantities without limitation. He views positive and negative quantities as mathematical objects constructed in opposite directions - a fundamental concept for the construction of number lines (Schubring, 2005). Fischer deals with the delimitation of points on the number lines, making a graphical correspondence between the values of the variables $\mathrm{x}$ and $\mathrm{y}$ with their curve in a rectangular coordinate system (Figure 7) in the geometric representation of the expression $x^{3}-5 x^{2}+6=y$ (Schubring, 2005).

He explicitly associates each point on the axis of the abscissa with the values of $\mathrm{x}$ and corresponds to one point on the axis of the ordinate.

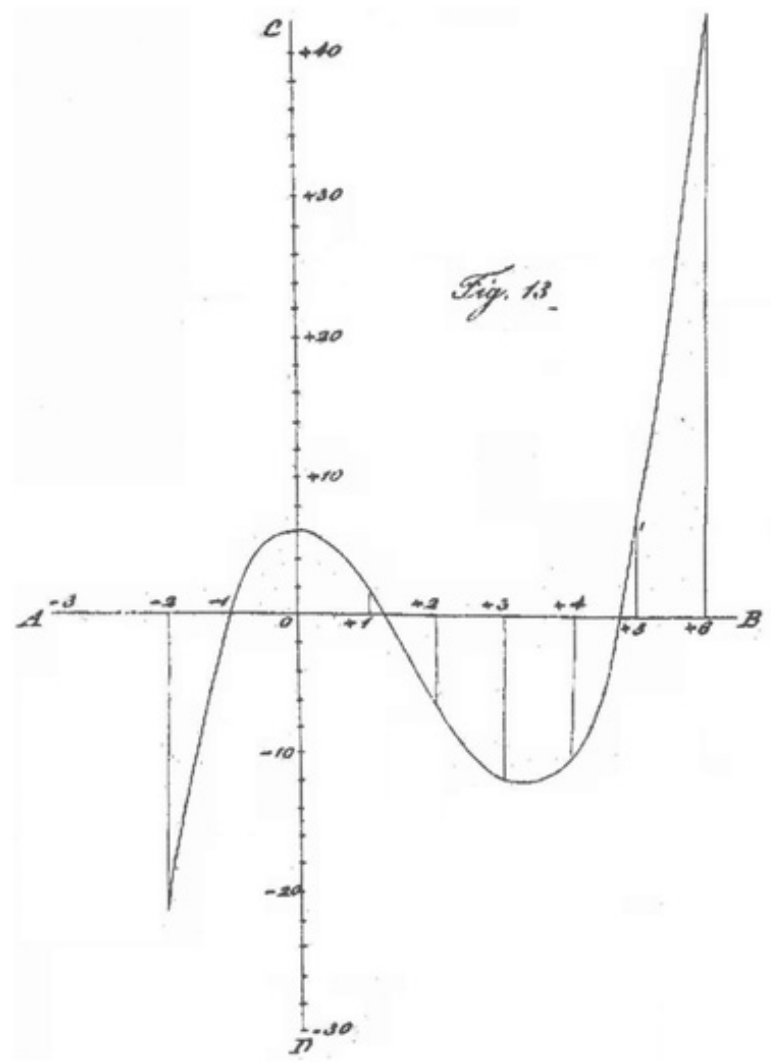

Figure 5. Fischer's coordinate system (1829).

Alongside the work of Fischer, the use of the concept of axis appears in Carl F. Gauß (1777-1855) in a publication in Theoria residuorum biquadraticum (1831). Gauß first considers the line of real numbers, taking into account the positive numbers in one direction and the negative numbers in the other. Gauß's contribution was to describe integers in a series of points in a line. While Fischer made a graphical recording of the number line, Gauß explains it verbally. Gauß's proposal was to work only with integers. He resorted to the concept of the line only to describe the integers in the same line (Amadeo, 2018). 
4th period. From the beginning of the 19th century to the present: The foundation of the number line in its present form.

During the 19th century, more abstract geometric theories began to emerge, which led to the creation of non-Euclidean geometries and the axiomatization of geometry. The creation of these geometries had the effect of changing the old concepts of mathematics. The emergence of mathematical contradictions due to unclear concepts, intuitive proofs and ambiguous expressions led the 19th-century mathematicians to realize that the mathematical construct had to be based on solid foundations. Thus, they tried to rigorously develop the system of real numbers and then base on it all the basic concepts of analysis.

The first attempt to develop a theory of real numbers was made in the early 1830s by Bolzano, who saw real numbers as limits of progressions of rational numbers (Boyer \& Merzbach, 1997). Around the same time, Rowan Hamilton (1805-1865) made an attempt to define real numbers, but could not escape the logic of ordinary geometric tradition (Crossley, 1987).

Meray (1835-1911) believed that there was a gap in mathematical logic from the time of Cauchy onwards. He thus defined the limit of a sequence as a real number and then defined a real number as a limit of a sequence of rational numbers. He essentially assumed that a convergent sequence had a rational or fictitious number as the limit. Fictitious numbers can be ordered and they are the known irrational numbers (Boyer \& Merzbach, 1997).

Karl Weierstrass (1855-1897), wanting to base infinite calculus solely on the concept of number, believed that he had to define irrational numbers irrespective of the concept of limit. He therefore considered the convergent sequence itself as the number or the limit. Therefore, irrational numbers are defined as sets of rational numbers, rather than ordered sequences of rational numbers (Boyer \& Merzbach, 1997).
In 1871, Georg Cantor (1845-1918) launched a new numbering program, similar to the Meray and Weierstrass programs. At the same time Heine (1821-1881) proposed some simplifications that led to the so-called Cantor-Heine development, which resembles that of Meray, in which convergent sequences that do not converge to rational numbers are considered to define irrational numbers.

However, the most imposing attempt at defining the real number was made by Dedekind (1831-1916). Dedekind believed that for the concept of the limit to be rigorous, it had to be developed within arithmetic and without the aid of geometry. Initially, he wondered in which way a continuous geometric size differs from rational numbers. While Galileo and Leibniz considered earlier that the continuity of points on a line was the result of their density, Dedekind observed that while the rational numbers have this property, they do not form a continuous one. He concluded, therefore, that the continuity of a straight segment is due to the nature of dividing a segment into two parts by one point in the segment. In each division, the points in the segment are divided into two classes, so that each point belongs to one single class, and each point of one class is to the left of each point in the other, and then there is a unique point which can do this division. This observation by Dedekind reveals the secret of continuity (Eves, 1997).

Dedekind tried to give a clear definition of continuity, first for the points of a straight line and then for a set of numbers starting from the set of rational numbers, after observing that the ordering properties of rational numbers apply just as the relations between the points of a straight line. However, not all arithmetic phenomena applied to points in a straight line can be applied to the set of rational numbers. Thus, the set of rational numbers is inadequate and should be supplemented with new numbers so that the new set can achieve the same completeness as the straight line (Mpantes, 2013). 
Dedekind considered that the set of rational numbers could be extended to a continuous set of real numbers if the Cantor-Dedekind principle accepted that the points of a straight line could be mapped one by one with the real numbers. So, we have the foundation of the number line in its current form.

\section{Difficulties of the use of number line in the education}

We did not exhaustively examine all the research carried out in the various areas of mathematical concepts where the number line is used as a tool, but we did selectively investigate the areas of natural numbers, fractions and irrational numbers.

The natural numbers and their operations on the number line

Diezmann et al. (2010) interviewed annually, over a 3-year period, 67 students (aged 10-12 years) on a total of six number line items drawn from the Graphical Languages in the Mathematics (GLIM) test. They argue that: "Although the structured number line can assist students' understanding of mathematics, our research indicates that some primary students experience difficulty with the number line" (Diezmann \& Lowrie, 2006; Lowrie \& Diezmann, 2005: 25). They found that at least $10 \%$ of the 67 students interviewed in their study were unsuccessful at the structured number line items. Solution errors were common. They included the difficulties with distance, position, counting or misreading the diagram. The use of a simple counting strategy was inappropriate because it would incorrectly assume that (a) the marked line segments were evenly spaced, and (b) the distance between each segment represented one unit. The spacing between markings of line segments can be variable on structured number lines with only some of the line segments marked. This means that the distance between the segments can represent any number of units. Consequently, students who used only the counting strategy were the most likely to be unsuccessful.
Skoumpourdi (2010) investigated the ways in which the number line can function in solving mathematical tasks by 32 Greek first graders (6 years old). Each student in the experiment was given one of the two versions of a written test. One version consisted of word problems of addition or subtraction and the other version consisted of the same problems accompanied by a number line. The results of this study showed that students had difficulty in interpreting the number line representation and in translating the problem to the number line.

\section{Fractions and number line}

Many studies show that students encounter several difficulties in introducing the number line into fractions and using it as a visual model (Bright, Behr, Post \& Wachsmuth, 1988; Clarke, Roche \& Mitchell, 2007; Hannula, 2003; Mitchell \& Horne, 2008; Petit, Laird, Marsden \& Ebby, 2010; Pearn \& Stephens, 2007; Pettito, 1990; Saxe et al., 2007).

Bright et al. (1988) argue that an interpretation of this difficulty with the number line is related to its features as a model. The number line model consists of image information accompanied by symbols and it is difficult to connect the information contained in these two types of representation. As a result, the authors conclude: "A hypothesis arising out of this analysis is that the need to coordinate symbolic and pictorial information with the number line model poses difficulty in matching fraction names with number line representations" (Bright et al., 1988: 227).

When students first interact with the number line, they often operate with the natural numbers logic and place the fractions on the numerator in the order of their numerator or denominator size (Figure 6) (Petit, Laird, Marsden \& Ebby, 2010).

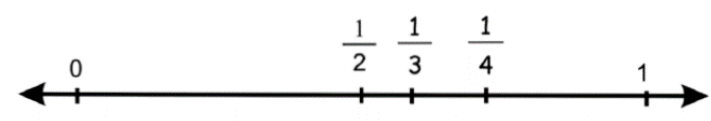

Figure 6. Number line with fractions on the numerator in the order of their numerator or denominator size. 
Students in the first three grades shift from succession strategies to proportion strategies to place numbers on the number line (Pettito, 1990). This means that students understand the proportion between distances and not just succession. For example, Figure 7 below shows that the fractions are positioned correctly in sequence but not proportionally.

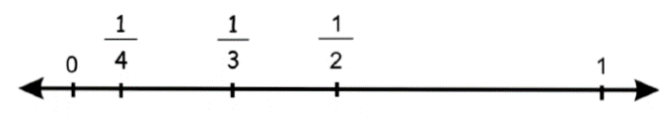

Figure 7. Number line with fractions positioned correctly in sequence but not proportionally.

Another common mistake in students' initial contact with the number line, when there are multiple units, is that they take the fractional part of the whole number line and not the unit part. For example, 2/3 is set to 4 (Clarke, Roche \& Mitchell, 2007).

Many times, instead of counting the intervals from zero to the fraction, students count the vertical small lines of the graduation of the number line (Bright, Behr, Post \& Wachsmuth, 1988; Pearn \& Stephens, 2007).

Students find it difficult to place fractions that have multiple coefficients (i.e., equivalents) with respect to the graduation of the number line (Hannula, 2003; Petit, Laird, Marsden \& Ebby, 2010). Students also face significant difficulties in the case where the graduation of the line is incomplete (Saxe et al., 2007).

Research shows that teachers need special training on the nature of the number line and on how it can be used as a tool in teaching various mathematical concepts. Without this training, teachers also find it difficult to use the number line (Gray \& Doritou, 2008; Teppo \& Van den Heuvel-Panhuizen, 2014; Van den Heuvel-Panhuizen, 2008).

\section{Irrational numbers and number line}

Fischbein, Jehiam \& Cohen (1995) examined the multitude of rational and irrational numbers, their density, and the relationship between the rational and irrational numbers and the points on the number line. To the question "Does a rational number correspond to every point on the number axis?" the correct answer being "no" was given by $40 \%$ in grade $9,47 \%$ in grade 10 and $66 \%$ by college students. Especially for the college students, the results must be considered as very bad. To the question "Is the following statement true: For every irrational number there is a corresponding point on the number axis." the correct answer ("yes") was given by $63 \%$ in grade $9 ; 56 \%$ in grade 10 , and $80 \%$ by the pre-service teachers. Students were also asked if the following statement was true: "Every point on the number axis has a corresponding real number". The correct answer ("yes") was given by $37 \%$ in grade $9,63 \%$ in grades 10 and $90 \%$ by college student.

Kidron (2016) argued that there are three different representations of irrational numbers; the first relates to their decimal representation, the second to the line of real numbers, and the third to the relationship between incommensurability and irrational numbers. Assigning any real number to a point on the number line is difficult to understand when one has never seen an irrational on the number line, especially given the fact that the line of numbers is dense with rational numbers (everywhere).

Sirotic and Zazkis (2007) conducted a study involving 46 secondary education teachers on how to represent the irrational number $\sqrt{5}$ at a point on the number line. Researchers deliberately chose $\sqrt{5}$ instead of $\sqrt{ } 2$, believing that $\sqrt{ } 2$ would lead some participants to automatically recall from their memory the value of $\sqrt{2}$ rather than construct it. The results of the research showed that the geometric representation of the irrational numbers didn't occur to most participants. The common perception of the real number line seems to be confined to the number line of rational numbers, or even more strict- 
ly, to the number line of decimal rational numbers, where only finite decimal numbers take their representations as "points in the number line".

Vamvakoussi and Vosniadou (2012) found that the analogy between points and numbers implicit in the use of the number line is not utilized by students. They found also that the infinity of points on a segment might be more accessible to students compared to the infinity of numbers in an interval.

Many studies show that students' initial conceptions of the points on a straight segment and also of the numbers in an interval might be limited and biased towards the idea of discreteness (Fischbein, 1987; Giannakoulias, Souyoul \& Zachariades, 2007; Hannula, Pehkonen, Maijala \& Soro, 2006; Tirosh \& Stavy, 1996; Vamvakoussi \& Vosniadou, 2004; 2007; 2010).

\section{Correlation between the historical evolution and the difficulties encountered in education}

First of all, we should note that the mathematical integration and constitution of the notion of the number line, as we know it today, took place very slowly in the history of mathematics. As we have seen, it was only with the foundations of Dedekind and Cantor in the late 19th and the early 20th century that we can now consider that there is a one-toone correspondence between the points of a straight line and the numbers of the set of real numbers. This in itself shows that while the concept of the number line appears to be simple, its composition to its present form has been long and developed through the four periods mentioned in the section $\mathrm{V}$.

As critical points in this mathematical constitution of the notion of number line over the course of mathematical history, we can in principle consider the separation between the numbers and the magnitude or the separation between the numbers and the straight line, as presented in historical analysis in the first period (V.1). We can see this separation, as we indicated above, in the mistakes of stu- dents who often manage numbers separately from the measures on the straight lines of numbers. We saw such errors in the natural numbers, but also in the fractions. This difficulty is also interpreted from the semiotic point of view, when a simultaneous management of two different registers in a concept is needed. In this case, we have the simultaneous management of arithmetic (numbers) and geometric (measures) register. This fact creates additional difficulties for students in their attempt to manage the number line (Duval, 1988).

This difficulty, which refers to the division between number and magnitude, can arise from the simpler types of the number line that we use, such as the first type of filled number lines reported by Teppo \& Van den Heuvel-Panhuizen (2014) to the most complex number lines (fifth type).

The second critical point that appears in the historical evolution, but also as a difficulty for students, is the negative numbers and the orientation on the number line in the positive or negative direction.

As we have already seen in the historical evolution of the number line in the second period (V.2) of the 16th century, Stifel recognizes the negative numbers and places them to the left of zero. The difficulties of students concerning managing negative numbers on the number line is also highlighted in the Heeffer (2011) and Thomaidis \& Tzanakis (2007) research mentioned in Chapter III. The third type of number line, the 'directed - length number lines' reported by Teppo \& van den Heuvel-Panhuizen (2014), requires this ability of orientation on the number line.

The third critical point is the density of rational numbers and the extra unit intervals needed to place them on the line of numbers. This occurs in students' difficulties when placing fractions and generally rational numbers on the number line where it is necessary to determine the extra unit space such as, for example, specifying the unit of $1 / 4$ to place $3 / 4$ on the number line. We saw that this was one of the points 
of difficulty and mistakes of the students in the fractions in Chapter VI. Another point of difficulty for students, as well as teachers, is the concept of the density of rational numbers. That refers to understanding that between two rational numbers there are infinite others (e.g. Lemonidis, Tsakiridou \& Meliopoulou, 2018; Vamakoussi \& Vosniadou, 2004; 2007; 2010).

We have observed that in the historical revolution that during the second (V.2) and third (V.3) periods the formation and symbolic expression of rational numbers in numbers as well as the algebraization of geometry and the conditions for the placement of rational numbers on the number line were developed. This ability to determine the extra unit measure required by students is described by Teppo and Van den Heuvel-Panhuizen (2014) in the rational number line (the fourth type).

The fourth critical point focuses on the density of the irrational numbers, the separation of the rational from the irrational numbers, and the representation of the irrational numbers on the number line.

In paragraph VI we examined the difficulties of students and teachers of mathematics regarding the density and separation of rational and irrational numbers and the representation of irrational numbers on the number line.

As it was pointed out drawing on historical information, the identification of real numbers and their correspondence with points on the number line reaches its conclusion very late, actually between the late $19^{\text {th }}$ and the early $20^{\text {th }}$ century. The historical evolution and constitution of these issues are presented during the fourth period (V.4) of the historical evolution, as presented above.

\section{Discussion - Conclusion}

In this work we distinguish mathematical number lines, such as the axis, from their representations of the graduated and the empty number line. We believe that graduated number lines are closer to the mathematical axis and retain its components rather than the empty number line. In our historical analysis the axis is the mathematical object considered, when referring to the number line, and we distinguish four periods regarding its evolution. First of all, it must be emphasized that the completion of the concept of the axis during the history of mathematics took place very late. The same conclusion was reached in the Amadeo (2018) research. This in itself shows that the concept of number line is not simple, although it seems to be so.

By comparing the historical evolution of the number line with the difficulties of the students, the first critical point seems to be drawn by the separation between the numbers and the magnitude or the separation between the numbers and the straight line. The second critical point is drawn by the negative numbers and the orientation on the number line in the positive or the negative direction. The above mentioned are reflected both in the historical development and in the difficulties of the students, also highlighted by Thomaidis \& Tzanakis (2007) and Heefer (2011). The third critical point is drawn by the density of rational numbers and the extra unit intervals needed to place them on the line of numbers. Finally, the fourth critical point is drawn by the density of the irrational numbers, the separation of the rational from the irrational numbers and the representation of the irrational numbers on the number line. The above four critical points are a source of difficulty for students as well as adults, and we also find them in students' mistakes.

More research is needed on both the history of mathematics and the behavior of students to clarify the nature of these difficulties. If the difficulties concerning these critical points comprise epistemological obstacles in the sense that Brousseau (1983) pointed it out, they should be specifically addressed by the teaching procedure and should be overcome. Teppo \& Van den Heuvel-Panhuizen, (2014) provide some such highlights as well as suggestions for the teaching of number lines. 
This study examined the students' difficulties regarding mathematical concepts of natural numbers, fractions and irrational numbers, where the number line is used as a model for teaching. This research could be extended to the difficulties of pupils and adults, as well as to other areas of mathematical concepts, where the number line is applied as a mathematical concept. Such examples of con- cepts can be found in geometry, in vector geometry, in measurements on lines, in inequations, etc. For example, in our research (Lemonidis, 1990, 1991) on French high school students we found that they encountered serious difficulties when asked to apply the geometric transformation of homothety to very simple situations, i.e., to a point in a graduated line.

\section{References}

- Amadeo, M. (2018). Textbooks revealing the development of a concept - the case of the number line in the analytic geometry (1708-1829). ZDM, 50 (5), 907-920. DOI: 10.1007/s11858-018-0968-7

- Bachelard, G. (1938). La formation de lesprit scientifique. Paris: J Vrin.

- Beishuizen, M. (1999). The empty number line as a new model. In: Thompson, I. (ed.) Issues in teaching numeracy in primary schools (157-168). Buckingham: Open University Press.

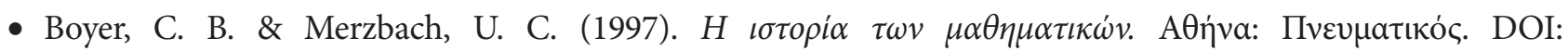
$10.2307 / 2532593$ [The history of mathematics] [in Greek].

- Bright, G. W., Behr, M. J., Post, T. R. \& Wachsmuth, I. (1988). Identifying fractions on number lines. Journal for Research in Mathematics Education, 215-232. DOI: 10.2307/749066

- Brousseau, G. (1976). Les obstacles épistémologiques et les problèmes en mathématiques. In: Comptes-rendus de la XXVIIIème rencontre organisée par la Commission Internationale pour l'Etude et l'Amélioration de l'Enseignement des Mathématiques (101-117). Louvain-la-Neuve.

- Brousseau, G. (1983). Les obstacles épistémologiques et les problèmes en mathématiques. Rech Didact Math, 4 (2), 165-198.

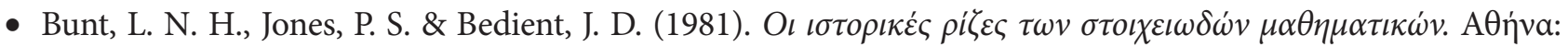

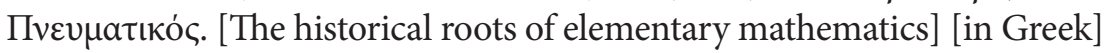

- Chambers, E. (1728). Cyclopaedia; or An universal dictionary of arts and sciences (Vol. 1-2). London: Printed for James and John Knapton.

- Clarke, D. M., Roche, A. \& Mitchell, A. (2007). Year six fraction understanding: A part of the whole story. In: Watson, J. \& Beswick, K. (Eds.). Proceedings of the 30th annual conference of the Mathematics Education Research Group of Australasia (MERGA): Mathematics: Essential research, essential practice Vol. 1 (207-216). Sydney: MERGA.

- Crossley, J. N. (1987). The Emergence of Number. World Scientific Publishing Co Pte Ltd. DOI: 10.1142/0462

- Dickinson, P. \& Eade. F. (2004). Using the number line to investigate the solving of linear equations. For the Learning of Mathematics, 24 (2), 41-47.

- Diezmann, C. M., Lowrie, T., \& Sugars, L. (2010). Primary students' success on the structured number line. Australian Primary Mathematics Classroom, 15 (4), 24-28.

- Diezmann, C. M. \& Lowrie, T. (2006). Primary students' knowledge of and errors on number lines. In: Grootenboer, P., Zevenbergen, R. \& Chinnappan, M. (Eds.). Proceedings of the 29th annual conference of the Mathematics Education Research Group of Australasia: Identities, cultures, and learning spaces (171-178). Sydney: MERGA. 
- Duroux, A. (1983). La valeur absolue: difficultés majeures pour une notion mineure. Petit x, 3.

- Duval, R. (1999). Representation, vision and visualization: Cognitive functions in mathematical thinking. Basic issues for learning. In: Hitt, F. \& Santos, M. (Eds.). Proceedings of the Twenty First Annual Meeting of the North American Chapter of the International Group for the Psychology of Mathematics Education (3-26). Columbus, $\mathrm{OH}$ : Clearinghouse for Science, Mathematics, and Environmental Education.

- Duval, R. (1988). Graphiques et equations: l'articulation de deux registres. Annales de Didactique et de Sciences Cognitives, 1, 235-255.

- Eves, H. W. (1997). Foundations and fundamental concepts of mathematics. Mineola, New York: Dover Publications, Inc.

- Fischbein, E. (1987). Intuition in science and mathematics. Dordrecht, Netherlands: Kluwer Academic Publishers.

- Fischbein, E., Jehiam, R. \& Cohen, C. (1995). The concept of irrational number in high-school students and prospective teachers. Educational Studies in Mathematics, 29, 29-44. DOI: 10.1007/bf01273899

- Giannakoulias, E., Souyoul, A. \& Zachariades, T. (2007). Students' thinking about fundamental real numbers properties. In: Pitta-Pantazi, D. \& Philippou, G. (Eds.). Proceedings of the Fifth Congress of the European Society for Research in Mathematics Education (426-425). Cyprus: ERME, Department of Education, University of Cyprus.

- Glaeser, G. (1981). Epistémologie des nombres relatifs. Rech Didact Math, 2-3, 303-346.

- Gray, E. \& Doritou, M. (2008). The number line: Ambiguity and interpretation. In: Figueras, O., Cortina, J. L., Alatorre, S., Rojano, T. \& Sepu'lveda, A. (Eds.). Proceedings of the joint Meeting of PME 32 and PME-NA XXX Vol. 3 (97-104). Mexico: Cinvestav-UMSNH.

- Hannula, M. S. (2003). Locating fractions on a number line. In: Pateman, N. A., Dougherty, B. J. \& Zilliox, J. T. (Eds.). Proceedings of the 27th Conference of the International Group for the Psychology of Mathematics Education held jointly with the $25^{\text {th }}$ Conference of PME-NA Vol. 3 (3-24). Honolulu, HI: PME.

- Hannula, M. S., Pehkonen, E., Maijala, H. \& Soro, R. (2006). Levels of students' understanding on infinity. Teaching Mathematics and Computer Science, 4 (2), 317-337. DOI: 10.5485/TMCS.2006.0129

- Heefer, A. (2011). Historical objections against the number line. Science \& Education, 20 (9), 863-880. DOI: 10.1007/s11191-011-9349-0

- Katz, U. K. \& Katz, G. M. (2011). Stevin Numbers and Reality. Foundations of Science, 17 (2), 109-123. DOI: 10.1007/s10699-011-9228-9

- Kidron, I. (2016). Understanding irrational numbers by means of their representation as non-repeating decimals. In: Nardi, E., Winsløw, C. \& Hausberger, T. (Eds.). First conference of International Network for Didactic Research in University Mathematics (73-83). Mar 2016, Montpellier, France. hal-01337883f.

- Lemonidis, C. (1990). Conception, réalisation et résultats d'une expérience d'enseignement de l'homothétie (Thèse de Doctorat). Université Louis Pasteur, I.R.E.M. de Strasbourg. DOI: 10.12681/eadd/3786

- Lemonidis, C. (1991). Analyse et réalisation d'une expérience d’enseignement de l'homothétie. Recherches en Didactique des Mathématiques (R.D.M), 11 (2-3), 295-324.

- Lemonidis, C., Tsakiridou, H. \& Meliopoulou, I. (2018). In-Service Teachers' Content and Pedagogical Content Knowledge in Mental Calculations with Rational Numbers. International Journal of Science and Mathematics Education, 16 (6), 1127-1145. DOI: 10.1007/s10763- 017-9822-6.1 
- Lowrie, R., \& Diezmann, C. M. (2005). Fourth-grade students' performance on graphical languages in mathematics. In: Chick, H. L. \&. Vincent, J. L (Eds.). Proceedings of the 30 th Annual Conference of the International Group for the Psychology of Mathematics Education Vol 3 (265-272). Melbourne: PME.

- Mitchell, A. \& Horne, M. (2008). Fraction number line tasks and the additivity concept of length measurement. In: Proceedings of the 31st annual conference of the mathematics education research group of Australasia (353-360).

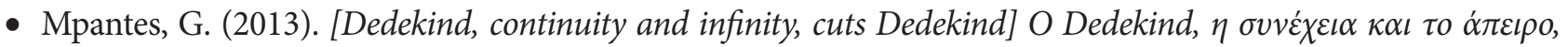
$\tau o \mu \varepsilon ́ \varsigma$ Dedekind. Retrieved from: https://www.scribd.com/doc/147611828/ last access to 21/06/2019. [in Greek]

- Murphy, C. (2011). Comparing the use of the empty number line in England and the Netherlands. British Educational Research Journal, 37 (1), 147-161. DOI: 10.1080/01411920903447423

- Murphy, C. (2008). The use of the empty number line in England and the Netherlands. Proceedings of PME, 32 (4), 9-16.

- Neal, K. (2002). From discrete to continuous. The broadening of number concepts in early modern England. Melbourne: R.W Home, University of Melbourne.

- Núñez, R. E. (2011). No innate number line in the human brain. Journal of Cross-Cultural Psychology, 42 (4), 651-668. DOI: 10.1177/0022022111406097

- Pearn, C. \& Stephens, M. (2007). Whole number knowledge and number lines help develop fraction concepts. In: Watson, J. \& Beswick, K. (Eds.). Proceedings of the 30th annual conference of the Mathematics Education Research Group of Australasia (MERGA): Mathematics: Essential research, essential practice Vol. 2 (601-610). Hobart, Sydney: MERGA.

- Petit, M. M., Laird, R. E., Marsden, E. L. \& Ebby, C. B. (2010). A focus on fractions: Bringing research to the classroom. London: Routledge.

- Petitto, A. (1990). Development of number line and measurement concepts. Cognition and Instruction, 7 (1), 55-78. DOI: 10.1207/s1532690xci0701_3

- Pycior, H. (1987). British abstract algebra: development and early reception. Cahiers d'Histoire et de Philosophie des Sciences, 21, 152-168.

- Roque, T. (2012). Historia da matematica: uma visyo critica, desfazendo mitos e lendas. Rio de Janeiro: Jorge Zahar.

- Saxe, G. B., Shaughnessy, M. M., Shannon, A., Langer-Osuna, J. M., Chinn, R. \& Gearhart, M. (2007). Learning about fractions as points on a number Line. In: Martin, W. G., Strutchens, M. E. \& Elliott, P. C. (Eds.). The learning of mathematics: Sixty-ninth yearbook (221-237). Reston, VA: National Council of Teachers of Mathematics.

- Schubring, G. (2005). Conflicts between generalization, rigor, and intuition. Number concepts underlying the development of analysis in 17-19 $9^{\text {th }}$ century France and Germany. New York: Springer. DOI: 10.1007/0-387-28273-4

- Schubring, G. (1986). Ruptures dans le statut mathématique des nombres négatifs. Petit x, 12, 5-32.

- Sinkevich, G. (2015). On the History of Number Line. Saint Petersburg: Department of Mathematics, Saint Petersburg State University of Architecture and Civil Engineering. Retrieved January 18, 2020 from www: https:// www.academia.edu/20922833/On_the_history_of_number_line.

- Sirotic, N. \& Zazkis, R. (2007). Irrational numbers on the number line - where are they? International Journal of Mathematical Education in Science and Technology, 38 (4), 477-488. DOI: 10.1080/00207390601151828 
- Skoumpourdi, C. (2010). The number line: An auxiliary means or an obstacle? International Journal for Mathematics Teaching and Learning (Electronic Journal).

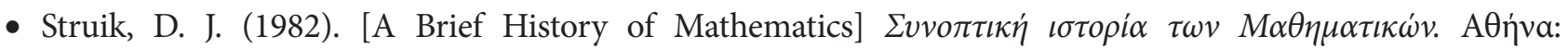
Zахаро́тои入ос. [in Greek]

- Teppo, A. \& Van den Heuvel-Panhuizen, M. (2014). Visual representations as objects of analysis: the number line as an example. ZDM, 46 (1), 45-58. DOI: 10.1007/s11858-013-0518-2

- Thomaidis, Y. (1995). Didactic transposition of mathematical concepts and learning obstacles (The case of absolute value) (doctoral thesis). Greece: Aristotle University of Thessaloniki. [in Greek]

- Thomaidis, Y. \& Tzanakis, C. (2007). Historical evolution and students' conception of the order relation on the number line: the notion of historical "parallelism" revisited. Educational Studies in Mathematics, 66, 165-183. DOI: $10.1007 / \mathrm{s} 10649-006-9077-6$

- Tirosh, D. \& Stavy, R. (1996). Intuitive rules in science and mathematics: The case of "everything can be divided by two". International Journal of Science Education, 18, 669-683. DOI: 10.1080/0950069960180603

- Treffers, A. (1993). Wiskobas and Freudenthal: realistic mathematics education. Educational Studies in Mathematics, 25 (1-2), 89-108. DOI: 10.1007/978-94-017-3377-9_6

- Van den Heuvel-Panhuizen, M. (2008). Learning from "Didactikids": An impetus for revisiting the empty number line. Mathematics Education Research Journal, 20 (3), 6-31. DOI: 10.1007/bf03217528

- Van den Heuvel-Panhuizen, M. (2003). The didactical use of models in realistic mathematics education: An example from a longitudinal trajectory on percentage. Educational Studies in Mathematics, 54 (1), 9-35. DOI: 10.1023/b:educ.0000005212.03219.dc

- Van der Waerden, B. L. (1985). A history of algebra. From al-Khwarizmi to Emmy Noether. Berlin: SpringerVerlag.

- Vamvakoussi, X. \& Vosniadou, S. (2012). Bridging the gap between the dense and the discrete: The number line and the "rubber line" bridging analogy. Mathematical Thinking and Learning, 14 (4), 265-284. DOI: $10.1080 / 10986065.2012 .717378$

- Vamakoussi, X. \& Vosniadou, S. (2010). How many decimals are there between two fractions? Aspects of secondary school students' understanding of rational numbers and their notation. Cognition and Instruction, 28, 181-209. DOI: 10.1080/07370001003676603

- Vamvakoussi, X. \& Vosniadou, S. (2007). How many numbers are there in an interval? Presuppositions, synthetic models and the effect of the number line. In: Vosniadou, S., Baltas, A. \& Vamvakoussi, X. (Eds.). Reframing the conceptual change approach in learning and instruction (267-283). Oxford, UK: Elsevier.

- Vamvakoussi, X. \& Vosniadou, S. (2004). Understanding the structure of the set of rational numbers: A conceptual change approach. Learning and Instruction, 14, 453-467. DOI: 10.1016/j.learninstruc.2004.06.013

- Waerden, B. L. (1985). A history of algebra: from Al-Khwārizmī to Emmy Noether. Springer.

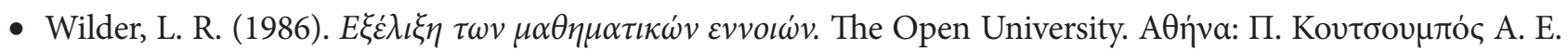
[The evolution of mathematical concepts] [in Greek] 


\section{Харалампос Е. Лемонидис}

Универзитет Западне Македоније, Факултет друштвено-хуманистичких наука, Одсек за основно образовање, Флорина, Грчка

\section{Анастасиос Ц. Голфос}

Четврта гимназија Евозмос, Солун, Грчка

\section{БРОЈЕВНА ПРАВА У ИСТОРИЈИ МАТЕМАТИКЕ И МАТЕМАТИЧКОМ ОБРАЗОВАњУ}

У овом раяу йрво йреgстиввљамо истираживана везана за йему раяа и анализирамо

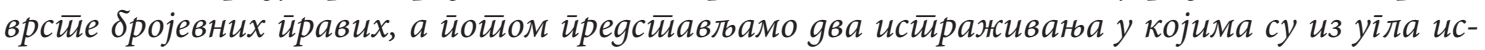

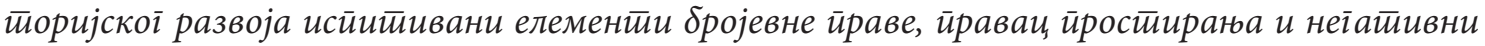
бројеви. У раяу затиим вршимо истиоријску анализу еволуиије йојма бројевне ирраве и йреg-

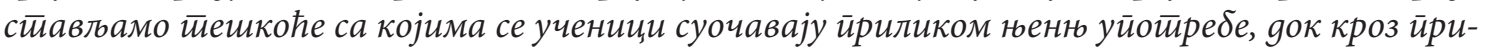
каз истиоријскоі развоја бројевне йраве йокушавамо да саїлеgамо ове ииешкоће у оgносу на

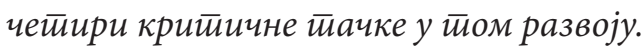

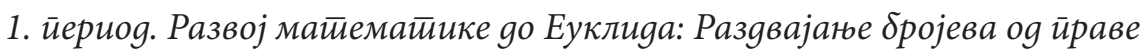

У анйичкој Грчкој је у матиематичи иостиојала јасна разлика између броја и величине.

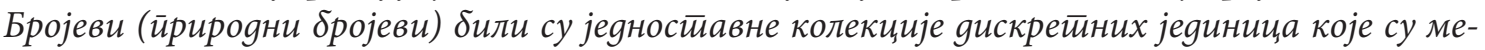

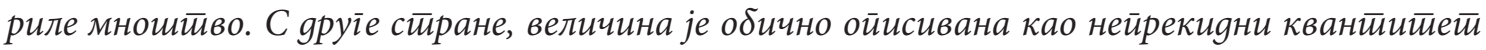
йоделен на gелове који се бесконачно може gелийи. Ова разлика између броја и величине gо-

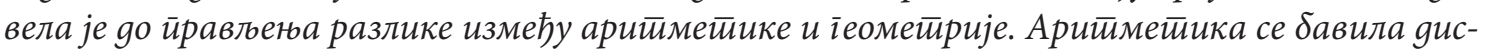

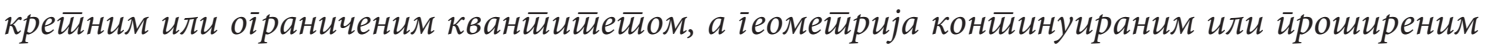

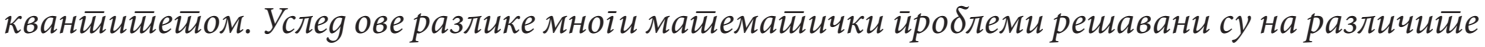
начине.

2. йериоg. До 16. века: Основе иелих бројева - Рачионални бројеви - Емитиријска іеомет̈рија

У йериоgy og 12. gо 16. века уочава се оријенйаиија ка емйиријској іеомеитрији, као и

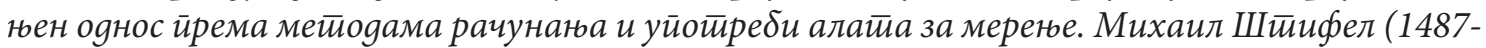

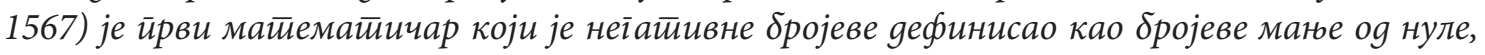
а йозитинвне бројеве као бројеве веће оg нуле. Први је и ойиса нулу, као и рационалне и ирационалне бројеве. У йоку 16. века дошло је до йромене класичноі схвайана йојма броја и величине. Франсоа Вијети (1540-1603) је увео нове симболе за означаване нейознайих величина и бројева, йврgећи gа су бројеви и величине међусобно заменљиви. Из овако схваћеноі

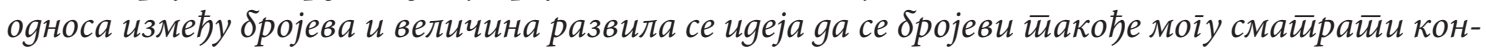

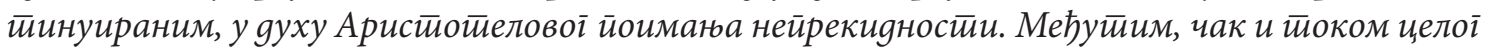

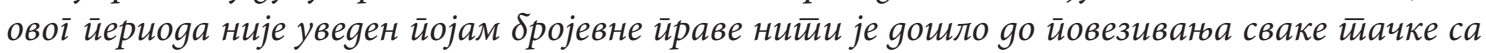




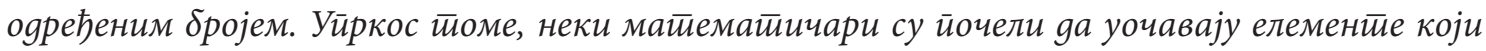
йако нешйо омоїућавају.

3. йериоg. Og 17. gо ӣочейка 19. века: Прво ӣовезиваюе бројева и іеометиријских яужи - аліе баризација іеометирије

Иgеја о бројевној йравој није заживела међу майемаичичарима све gо краја 16. века.

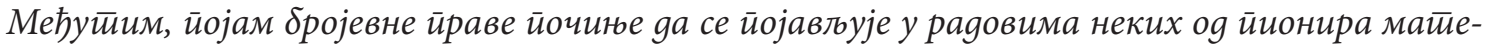

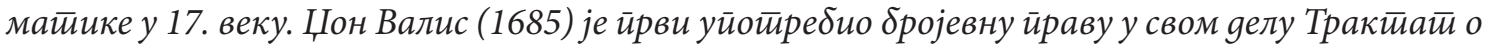
аліе бри (Treatise of Algebra), како би иротиумачио сабиране и оgузимане неїайивних бројева. Развој аліебарских симбола и йовезиваюе криве са юој оgїоварајућим једначинама довело је

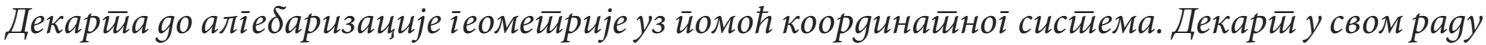

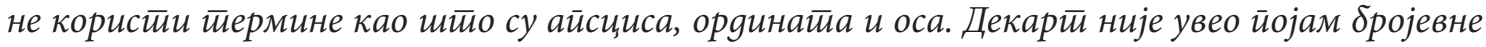

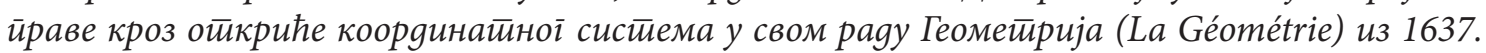
іодине, с обзиром на чиюенииу gа он никаяа не сиоомие йојам осе, нитии су осе или систием кооряинатиа йриказани на юеїовим илустирацијама, чак ни онgа каgа јасно оgређује вреgностии йојеgиних величина. Бројевна йрава се иррви йуй сйомиғе у йрвој иоловини 19. века у gелу Ернестиа Гойфрияа Фишера (1754-1831). Фишер се бавио неоіраниченим неїативним и

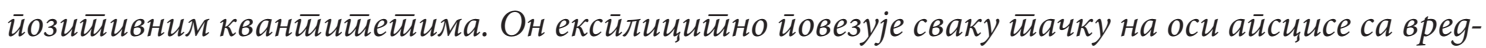
ностичма $x$ и оgі̄оварајућу йачку на оси орgинайе.

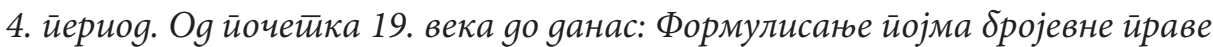

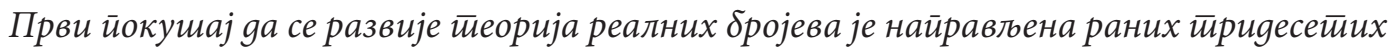
іодина 19. века оg сирране Болиана, који је реалне бројеве вияео као іраничне вреgностии ни-

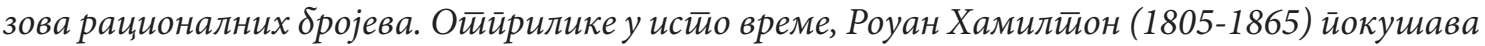
gа gебинише реалне бројеве, али није усиео яа ирревазиђе лоїику коју су намейала устиалена

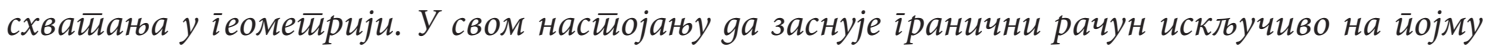

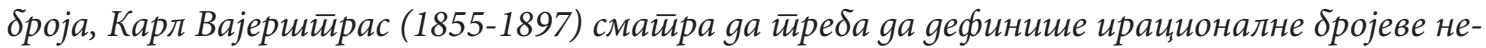

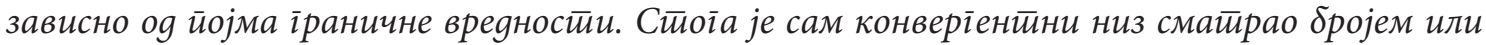
іраничном вреgношћу и gебинисао је ирационалне бројеве као скуйове рационалних бројева, ире неі̄о уређене низове раиионалних бројева. Георі Канйор (1845-1918) је 1871. їоgине сйворио нову кониейцију броја, сличну са концейцијом Мереа и Вајерийраса. У исйо време, Хајне

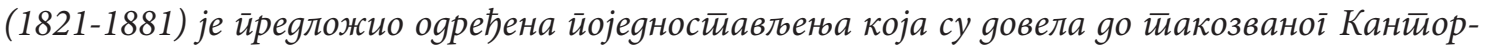
Хајнеовоі развоја, који ӣоgсећа на Мереов у коме конверіенйни низови који не конверіирају ка рационалним бројевима се узимају као яефиниција ираиионалних бројева.

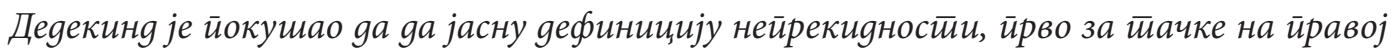
линији, а затиим и за скуй бројева йолазећи ов скуйа рационалних бројева, а након шито је

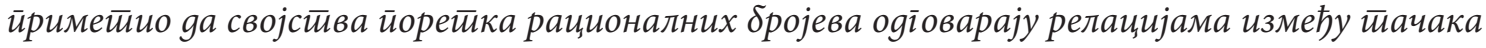

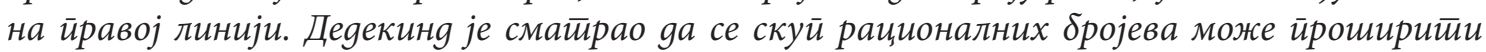
gо нейрекияноі скуйа реалних бројева ако се ирихватии Канйор-Деgекиндов ирриниий иррема коме се йачке на йравој линији моїу јеgан-јеgан йресликаванем йовезайи са реалним бројевима. Из овоїа ирроисииче засниване бројевне йраве у данашюој форми. 


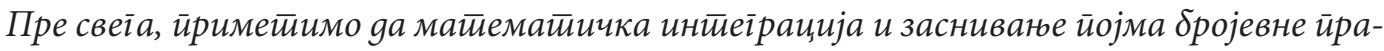
ве у данашнем смислу се у истиорији матиематиике одиіравала веома сйоро. Као шито смо моілли gа вияимо, захвалујући йостивкама Деgекинда и Канитора крајем 19. и йочеиком 20. века, ми саgа смайрамо gа йостиоји јеgан-јеgан йовезиване између йачака на ирравој и бројева у скуйу реалних бројева. То само йо себи указује gа је, иако йојам бројевне йраве изілтеgа јеgностиван за разумеване, за формулисаюе юеної данашюеі облика йребало мноїо времена.

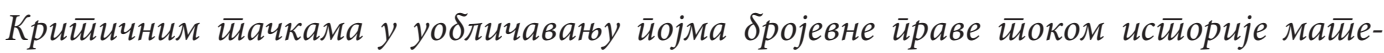

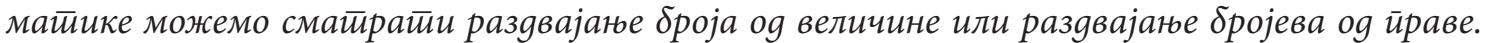

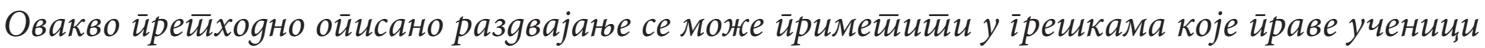

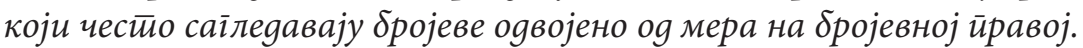

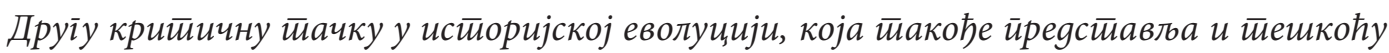

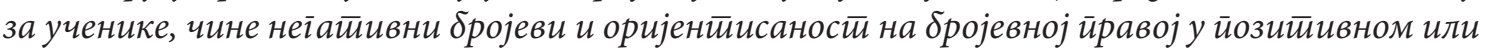
неїайивом смеру.

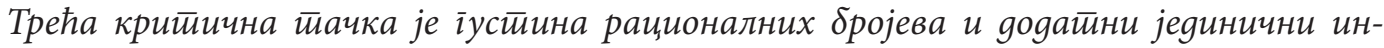

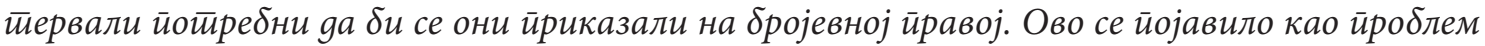
за ученике каяа су йребали gа сместие разломке на бројевној иравој, и рационалне бројеве

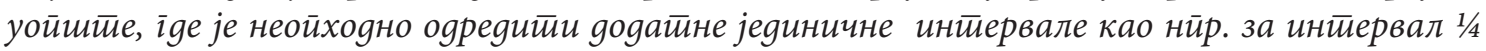
чиме би се оgреgио разломак $3 / 4$ на бројевној ирравој.

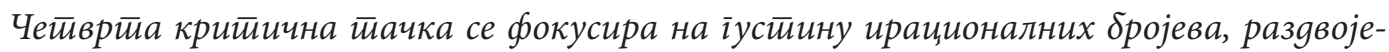
ности рационалних оg ирационалних бројева, и иреgстиављане ирационалних бројева на бројевној ирравој.

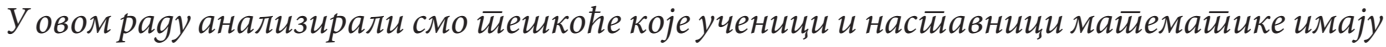
бавећи се іуустином и разgвојеношћу рационалних оg ирационалних бројева, као и йреgстиављанем ирационалних бројева на бројевној ирравој. Као шимо смо раније исииакли, и йозивајући се на истиоријске изворе, gо ияенйификоваюа реалних бројева и юиховоі йрияруживана са йачкама на бројевној ирравој дошло је врло касно, йек крајем 19. и йочеиком 20. века.

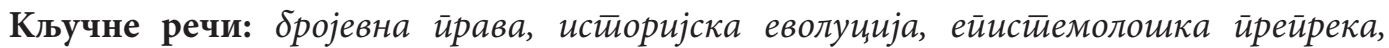
йредйсииявљаюе йојмова. 